\title{
DETERMINAN PENGUNGKAPAN LKPD PADA WEBSITE RESMI PEMERINTAH DAERAH PROVINSI DI INDONESIA TAHUN 2017
}

\section{DETERMINANT DISCLOSURE OF LKPD IN THE OFFICIAL WEBSITE OF THE PROVINCIAL GOVERNMENT IN INDONESIA IN 2017}

\author{
Rizqa Puspita Nurhidayati1); Sri Rahayu²) \\ 1)Telkom University - Bandung \\ 2)Telkom University - Bandung \\ Email : rizqa.puspita19@gmail.com dan srirahayu@telkomuniversity.ac.id
}

\begin{abstract}
ABSTRAK
Penelitian ini memuat tiga faktor yang mempengaruhi suatu pemerintah daerah dalam mengungkapkan laporan keuangannya pada website resmi pemerintah daerah, tiga faktor tersebut yaitu, kondisi keuangan, kekayaan daerah, dan kesejahteraan masyarakat. Penelitian ini menggunakan metode kuantitatif yaitu metode yang menggambarkan fenomena atau gejala sosial yang terjadi di masyarakat saling berhubungan satu sama lain. Teknik pengambilan sampelnya menggunakan sampel jenuh. Penelitian ini menggunakan sampel laporan keuangan dari 34 provinsi yang ada di Indonesia pada tahun 2017. Hasil dari penelitian yang dilakukan adalah secara simultan semua variabel independen berpengaruh signifikan terhadap variabel dependen. Sedangkan secara parsial hanya variabel kekayaan daerah berpengaruh positif signifikan terhadap pengungkapan laporan keuangan pada website resmi pemerintah daerah tahun 2017.

Kata Kunci: Kondisi Keuangan, Kekayaan Daerah, Kesejahteraan Masyarakat Pengungkapan Laporan Keuangan
\end{abstract}

\begin{abstract}
This study includes three factors that influence a local government in disclosing financial statements on the official website of a local government, four factors namely, financial conditions, regional wealth, and public welfare. This study uses a quantitative method that is a method that describes social phenomena or phenomena that occur in the community are interconnected with each other. The sampling technique uses saturated samples. This study uses a sample of financial statements from 34 provinces in Indonesia in 2017. The results of the research carried out simultaneously all independent variables significantly influence the dependent variable. While partially only the regional wealth variable has a significant positive effect on the disclosure of financial statements on the official website of the 2017 regional government.

Keywords : Financial Condition, Regional Wealth, Public Welfare, Disclosure of Financial Statement
\end{abstract}




\section{PENDAHULUAN}

Transparansi informasi keuangan sangatlah penting dalam penyelengaraan pemerintah daerah demi mewujudkan pemerintahan yang bersih dan berintegritas (Idris, Surasani, \& Irawan, 2018). Hal ini dapat diwujudkan dengan melakukan pengungkapan Laporan Keuangan Pemerintah Daerah (LKPD) pada website resmi pemerintah daerah (Idris, Surasani, \& Irawan, 2018) . Menurut Undang-Undang No.71 tahun 2010 tentang Standar Akuntansi Pemerintahan (SAP), laporan Keuangan Pemerintah Daerah (LKPD) terdiri dari tujuh komponen yaitu, Laporan Realisasi Anggaran (LRA), Laporan Perubahan Saldo Anggaran Lebih (Perubahan SAL), Laporan Operasional, Laporan Perubahan Ekuitas, Neraca, Laporan Arus Kas, Catatan atas Laporan Keuangan (CaLK). Semakin banyak komponen dari LKPD yang diungkapkan dalam website resmi pemerintah daerah maka dapat menjadi indikasi semakin transparan daerah tersebut (Khasanah, Yuhertiana, \& B, 2017).

Terdapat banyak faktor yang dapat mempengaruhi suatu pemerintah daerah melakukan pengungkapan LKPD pada website resminya. Penelitian ini menggunakan tiga faktor yang pengaruhnya tidak konsisten dalam setiap penelitiannya yaitu, kondisi keuangan, kekayaan daerah dan kesejahteraan masyarakat. Penelitian ini bertujuan untuk menguji pengaruh antara variabel independen terhadap pengujian dependen. Sampel yang digunakan dalam penelitian ini adalah laporan keuangan dari ke-34 provinsi di Indonesia pada tahun 2017. Selain itu penelitian ini dilakukan untuk menguji pengaruh variabel independen secara simultan dan parsial terhadap variabel dependen.

\section{LANDASAN TEORI}

\section{Pengungkapan LKPD Melalui Website Resmi Pemerintah Daerah}

Pengungkapan (disclosure) laporan keuangan merupakan langkah terakhir dalam proses akuntansi berupa penyajian penyajian informasi yang relevan dalam bentuk laporan keuangan (Suwarjono, 2014). Pengungkapan laporan keuangan ditujukan untuk memberikan informasi keuangan kepada para pemangku kepentingan seperti kreditor, investor, pemerintah dan pihak lain yang berkepentingan (Suwarjono, 2014).

Pengungkapan laporan keuangan sendiri terdiri dari dua jenis yaitu pengungkpan wajib (mandatory) dan pengungkapan sukarela (voluntary) (Hendriyani \& Tahar, 2015). Pengungkapan wajib diatur dalam Undang-Undang No.17 tahun 2003 yang menyatakan bahwa setiap kepala instansi pemerintahan berkewajibann menyusun dan melaporkan laporan keuangan atas instansi yang dipimpinnya. Komponen yang harus disajkan dalam laporan keuangan terdiri dari Laporan Realisasi Anggaran (LRA), Laporan Perubahan Saldo Anggaran Lebih (Perubahan SAL), Laporan Operasional, Laporan Perubahan Ekuitas, Neraca, Laporan Arus Kas, dan Catatan atas Laporan Keunagan (CaLK) sesuai dengan Undang- Undang No. 71 tahun 2010 tentang Standar Akuntansi Pemerintahan. Sedangkan pengungkapan sukarela adalah pengungkapan informasi yang dilakukan secara sukarela oleh pemerintah dilaur informasi yang telah diatur dalam undangundang.

Variabel ini diukur menggunkan variable dummy yaitu apabila dalam website resmi pemerintah daerah terdapat satu atau lebih komponen LKPD maka akan diberi nilai 1, sedangkan apabila sama sekali tidak terdapat komponen LKPD maka diberi nilai 0 (Idris, Surasani, \& Irawan, 2018). 


\section{Pengembangan Hipotesis}

\section{Pengaruh Kondisi Keuangan Terhadap Pengungkapan LKPD pada Website Resmi Milik Pemerintah Daerah}

Kondisi keuangan adalah kemampuan yang dimiliki suatu pemerintah daerah untuk memenuhi kewajibannya, memberikan pelayanan kepada masyarakat, mengantisipasi kondisi tak terduga serta mengelola keuangan dengan efektif dan efisien (Rintoga, 2014). Dalam variable ini indikator yang digunkana dalah jumlah pendapatan daerah dan belanja daerah. Berikut ini rumus untuk menghitung kondisi keuangan suatu daerah:

$$
\text { Kondisi Keuangan }=\frac{\text { Jumalah Pendaptan-Belanja Daerah }}{\text { Belanja Daerah }}
$$

Semakin tinggi kondisi keuangan suatu daerah maka semakin tinggi kemungkinan suatu pemerintah daerah melakukan pengungkapan laporan keuangan pada website resminya (Khasanah, Yuhertiana, \& B, 2017). Daerah yang mempunyai kondisi keuangan dengan nilai lebih dari 0,1 dapat dikategorikan sebagai daerah dengan kondisi keuangan yang tinggi. Artinya, daerah tersebut sudah mampu mengelola keuangannya dengan baik yang ditandai dengan pendapatan daerah yang lebih tinggi daripada belanjanya. Hal ini diasumsikan bahwa semakin tinggi kondisi keuangan maka semakin tinggi pula belanja yang dapat dialokasikan untuk mengelola website resmi pemerintah daerah (Khasanah, Yuhertiana, \& B, 2017). Hal ini sejalan dengan penelitian yang dilakukan oleh Khasanah, et.al., (2017), Verawaty (2015) dan Rahim \& Martani (2015) yang hasilnya menyatakan bahwa kondisi keuangan berpengaruh positif terhadap pengungkapan LKPD pada website resmi pemerintah daerah. Data dari variabel ini dapat diakses melalui website resmi dari Kementerian Keuangan (djpk.kemenkeu.go.id).

H2 : Kondisi keuangan berpengaruh positif terhadap pengungkapan LKPD pada website resmi pemerintah daerah.

\section{Pengaruh Kekayaan Daerah Terhadap Pengungkapan LKPD pada Website Resmi Milik Pemerintah Daerah}

Kekayaan daerah adalah kemampuan pemerintah daerah untuk mengelola sumberdaya milik daerah yang bersangkutan serta pendapatan lain yang sah dari daerah tersebut (Putri \& Azra, 2019). Indikator dari kekayaan daerah dalam penelitian ini menggunakan Pendapatan Asli Daerah (PAD) (Hendriyani \& Tahar, 2015). PAD sendiri dari terdiri dari pajak daerah, retribusi, hasil dari daerah yang dipisahkan dan pendapatan lain yang sah (Ardiansyah, 2015). Berikut rumus yang digunakan dalam menghitung kekayaan daerah:

\section{Kekayaan Daerah $=\operatorname{Ln} P A D$}

Semakin tinggi kekayaan daerah maka akan menyebabkan keingintahuan masyarakat mengenai pengelolaan kekayaan daerah meningkat, hal ini dikarenakan tingginya kekhawatiran masyarakat akan penyelewengan dana yang dilakukan oleh pemerintah daerah (Verawaty, 2015). Hal ini diindikasikan menjadi motivasi pemerintah daerah dalam mengungkapkan informasi mengenai kekayaan daerah dalam website resminya (Istikomah \& Mutmainah, 2017).

Semakin tinggi kekayaan daerah maka semakin tinggi kemungkinan daerah untuk melakukan pengungkapan LKPD pada website resmi pemerintah daerah (Khasanah, Yuhertiana, \& B, 2017). Hal ini sejalan dengan hasil penelitian yang dilakukan oleh Khasanah, et.al., (2017), dan Istiqomah \& Mutmainah (2017), yang menyatakan bahwa kekayaan daerah berpengaruh 
positif terhadap pengungkapan laporan keuangan pemerintah daerah melalui website resmi pemerintah daerah. Data dari variabel ini dapat diakses melalui website resmi dari Kementerian Keuangan (djpk.kemenkeu.go.id).

H3 : Kekayaan daerah berpengaruh positif terhadap pengungkapan LKPD pada website resmi pemerintah daerah

\section{Pengaruh Kesejahteraan Masyarakat Terhadap LKPD pada Website Resmi Milik Pemerintah Daerah}

Kesejahteraan masyarakat dapat dilihat dari besarnya pendapatan perkapita suatu daerah atau disebut PDRB (Produk Domestik Regional Bruto) (Verawaty, 2015). Sedangkan PDRB sendiri merupakan indikator dari pertumbuhan ekonomi suatu daerah (Rahim \& Martani, 2016). Semakin tinggi kekayaan daerah maka semakin tinggi pengawasan politik (political monitoring) dari masyarakat terhadap kinerja pemerintah daerah dalam mengelola keuangan daerah (Verawaty, 2015). Indikator yang digunkan untuk menghitung kesejahteraan masyarakat adalah PDRB dan jumlah penduduk Berikut rumus yang digunakan untuk menghitung kesejahteraan masyarakat:

$$
\text { Kesejahteraan Penduduk }=\frac{\text { PDRB }}{\text { Jumlah Penduduk }}
$$

Semakin unıgı кеsejanteraan masyarakal veruarnpak paua semakin tingginya pengungkapan laporan keuangan yang dilakukan oleh pemerintah daerah pada website resminy (Rahim \& Martani, 2016). Tingginya kesejahteraan masyarakat mengindikasikan bahwa semakin tingginya pengawasan politik (political monitoring) yang dilakukan oleh masyarakat (Rahim \& Martani, 2016). Hal ini menjadi motivasi pemerintah daerah untuk melakukan pengungkapan LKPD pada website resminya. Selain itu hal ini dilakukan untuk mengurangi asimetri informasi diantara masyarakat (Verawaty, 2015). Hal ini sejalan dengan hasil penelitian yang dilakukan oleh Rahim dan Martani (2015), Nainggolan \& Purwanti (2016), Idris, et.al., (2018) yang menyatakan bahwa tingkat kesejahteraan masyarakat berpengaruh positif terhadap pengungkapan LKPD pada website pemerintah daerah. Data dari variabel ini dapat diakses melalui website resmi dari Badan Pusat Statistik (bps.go.id).

\section{H4 : Kesejahteraan Masyarakat berpengaruh positif terhadap pengungkapan LKPD pada} website resmi pemerintah daerah

\section{METODOLOGI PENELITIAN}

Penelitian ini menggunakan metode kuantitatif. Populasi dalam penelitian ini adalah laporan keuangan ke-34 provinsi di Indonesia pada tahun 2017. Penelitian ini menggunakan teknik pengambilan sampel jenuh. Analisis data dalam penelitian ini adalah analisis regresi logistik menggunakan aplikasi SPSS 20. Berikut persamaan dari regresi logistik:

$$
\operatorname{Ln} \frac{p}{1-p}=\beta 0+\beta X 1+\beta X 2+\beta X 3+
$$

Keterangan :

Ln $p /(1-p) \quad$ : pengungkapan informasi keuangan pada website resmi Pemerintah Daerah

Ln $p /(1-p)=1$ : pemerintah daerah mengungkapkan informasi keuangan pada website resmi pemerintah daerah 
$\operatorname{Ln} p /(1-p)=0:$ pemerintah daerah tidak mengungkapkan informasi keuangan pada website resmi pemerintah daerah

$\begin{array}{ll}\beta X 1 & : \text { kondisi keuangan } \\ \beta X 2 & : \text { opini audit } \\ \beta X 3 & : \text { kekayaan daerah } \\ \beta X 4 & : \text { kesejahteraan masyarakat } \\ \mathrm{e} & : \text { error/ kesalahan }\end{array}$

HASIL DAN PEMBAHASAN

Analisis Statistik Deskriptif

Tabel 1 Hasil Pengujian Statistik Deskriptif

\begin{tabular}{|c|c|c|c|c|c|}
\hline & $\mathrm{N}$ & Minimum & Maximum & Mean & Std. Deviation \\
\hline IFR & 34 & 0 & 1 & .44 & .504 \\
\hline Kondisi Keuangan & 34 & -.10 & .14 & .0021 & .04676 \\
\hline Kekayaan Daerah & 34 & 26.95 & 31.24 & 28.8324 & 1.15252 \\
\hline $\begin{array}{l}\text { Kesejahteraan } \\
\text { Masyarakat }\end{array}$ & 34 & 3.03 & 38.82 & 9.6906 & 7.27870 \\
\hline
\end{tabular}

Sumber: Data diolah SPSS 20

Berdasarkan Pengujian Analisis Deskriptif, dapat disimpulkan bahwa:

a. Kondisi keuangan daerah memiliki rata-rata sebesar 0,0021. Nilai maksimum kondisi keuangan sebesar 0,14. Nilai minimum kondisi keuangan daerah sebesar $-0,1$.

b. Kekayaan daerah memiliki rata-rata sebesar 28,8324 . Nilai maksimum kekayaan daerah sebesar 31,24. Nilai minimum kekayaan daerah daerah sebesar 26,95.

c. Kesejahteraan masyarakat memiliki rata-rata sebesar 9,6906. Nilai maksimum kesejahteraan masyarakat daerah sebesar 38,82. Nilai minimum kesejahteraan masyarakat sebesar 3,03.

d. Pengungkapan LKPD (IFR) memiliki rata-rata sebesar 0,44. Nilai maksimum pengungkapan LKPD (IFR) sebesar 1. Nilai minimum pengungkapan LKPD (IFR) sebesar 0 .

\section{Analisis Regresi Logistik}

Analisis regresi logistik pada dasarnya sama dengan analisis diskriminan, perbedaan terletak pada jenis data dari variabel dependen (Ghozali, 2018). Pada analisis ini variabel dependen menggunakan skala nominal (variabel dummy). Analisis regresi logistik merupakan alat analisis yang digunakan untuk mengukur seberapa jauh pengaruh variabel independen terhadap variabel dependen (Ghozali, 2018). Dalam analisis ini tidak dibutuhkan asumsi normalitas data pada variabel independennya, regresi logistik umumnya dipakai jika asumsi multivariat normal distribusi tidak terpenuhi (Ghozali, 2018). 


\section{Pengujian Kelayakan Regresi}

Tabel 2 Pengujian Kelayakan Model

\begin{tabular}{lccc}
\hline Step & Chi-square & df & Sig. \\
\hline 1 & 5.947 & 8 & .653 \\
\hline
\end{tabular}

Hasil pengujian Hosmer and Lemeshow dengan probabilitas signifikan menunjukkan angka 0,635 . Nilai signifikansi yang diperoleh lebih dari 0,05 sehingga HO diterima maka model penelitian ini dapat diterima karena sesuai dengan data observasinya.

\section{Pengujian Model Fit}

Tabel 3 Pengujian Model Fit

\begin{tabular}{ll}
\hline Langkah awal (block number $=0)$ & 46,662 \\
Langkah awal (block number $=1)$ & 38,823
\end{tabular}

Nilai -2LogL pada langkah awal (block number $=0$ ), dimana nilai konstantanya adalah sebesar 46,662 Sementara nilai -2LogL pada langkah selanjutnya (block number $=1$ ), dimana nilai konstanta sebesar 38,823. Hal ini menunjukkan penurunan -2LogL pada langkah awal dan 2LogL pada langkah selanjutnya sebesar 7,839. Penurunan ini menunjukkan model regresi yang semakin baik. sehingga model regresi ini layak digunakan untuk analisis selanjutnya.

\section{Pengujian Simultan (Omnibus Test of Model Coefficient)}

Tabel 4 Pengujian Simultan

\begin{tabular}{ccccc}
\hline & & Chi-square & df & Sig. \\
\hline \multirow{3}{*}{ Step 1 } & Step & 8.840 & 3 & .032 \\
& Block & 8.840 & 3 & .032 \\
& Model & 8.840 & 3 & .032 \\
\hline
\end{tabular}

Pengujian secara simultan dalam regresi logistik menunjukkan nilai dari Chi-Square sebesar 16,811 dengan tingkat signifikansi 0,002. Dengan demikian H01 ditolak dan Ha1 diterima yang berarti secara simultan variabel independen yaitu kondisi keuangan, kekayaan daerah dan kesejahteraan masyarakat berpengaruh terhadap variabel dependen yaitu pengungkapan informasi keuangan pada website resmi pemerintah daerah.

\section{Koefisien Determinasi}

\section{Tabel 5 Koefisien Determinasi}

\begin{tabular}{cccc}
\hline Step & $\begin{array}{c}-2 \text { Log } \\
\text { likelihood }\end{array}$ & $\begin{array}{c}\text { Cox \& Snell R } \\
\text { Square }\end{array}$ & $\begin{array}{c}\text { Nagelkerke R } \\
\text { Square }\end{array}$ \\
\hline 1 & $37.823^{a}$ & .229 & .307 \\
\hline
\end{tabular}


Hasil pengujian dengan nilai Nagelkerke R Square sebesar 0,307 (30,7\%) menunjukkan bahwa variabilitas variabel independen yaitu, kondisi keuangan, opini audit, kekayaan daerah dan kesejahteraan masyarakat mampu menjelaskan variabel dependen yaitu pengungkapan informasi keuangan pada website resmi pemerintah daerah sebesar $30,7 \%$ sisanya sebesar $69,3 \%$ dijelaskan oleh faktor lain diluar model penelitian ini.

\section{Pengujian Parsial (Variabel in The Equation)}

Tabel 6 Hasil Uji Koefisien Determinasi $\left(R^{2}\right)$

\begin{tabular}{|c|c|c|c|c|c|c|c|}
\hline & & B & S.E. & Wald & Df & Sig. & $\operatorname{Exp}(B)$ \\
\hline \multirow{4}{*}{$\begin{array}{l}\text { Step } \\
1^{a}\end{array}$} & KondisiKeuangan & -1.567 & 9.863 & .025 & 1 & .874 & .209 \\
\hline & KekayaanDaerah & 1.029 & .451 & 5.190 & 1 & .023 & 2.797 \\
\hline & $\begin{array}{l}\text { KesejahteraanMasy } \\
\text { arakat }\end{array}$ & .031 & .070 & .201 & 1 & .654 & 1.032 \\
\hline & Constant & -30.213 & 12.924 & 5.465 & 1 & .019 & .000 \\
\hline
\end{tabular}

Sumber: Data diolah SPSS 20

Berdasarkan hasil tersebut dapat diperoleh :

1. Nilai Sig. dari kondisi keuangan adalah 0,874 , dimana nilai tersebut lebih besar dibandingkan dengan nilai signifikansi $(a)=5 \%$ atau 0,05 . Maka $\mathrm{H} 02$ diterima, artinya tidak terdapat pengaruh antara kondisi keuangan dengan pengungkapan informasi keuangan pada website resmi pemerintah daerah.

2. Nilai Sig. dari kekayaan daerah adalah 0,023 , dimana nilai tersebut lebih besar dibandingkan dengan nilai signifikansi $(a)=5 \%$ atau 0,05 . Maka H03 diterima, artinya tidak terdapat pengaruh antara opini audit dengan pengungkapan informasi keuangan pada website resmi pemerintah daerah.

3. Nilai Sig. dari kesejahteraan masyarakat adalah 0,654 , dimana nilai tersebut lebih kecil dibandingkan dengan nilai signifikansi $(a)=5 \%$ atau 0,05 . Maka $\mathrm{H} 04$ ditolak, artinya terdapat pengaruh antara kekayaan daerah dengan pengungkapan informasi keuangan pada website resmi pemerintah daerah.

\section{Pembahasan}

\section{Pengaruh Kondisi Keuangan Terhadap Pengungkapan LKPD pada Website Resmi Pemerintah Daerah}

Hasil uji regresi logistik menunjukkan nilai signifikansi 0,874 yang lebih besar dari $\alpha=5 \%$ atau 0,05. Dari hasil ini dapat disimpulkan bahwa $\mathrm{H} 2$ ditolak, variabel kondisi keuangan secara parsial tidak berpengaruh secara signifikan terhadap pengungkapan LKPD pada website resmi pemerintah daerah. Hasil penelitian ini menunjukkan bahwa kondisi keuangan pemerintah daerah tidak menjadi acuan pemerintah daerah untuk melakukan pengungkapan informasi keuangan pada website resmi pemerintah daerahnya. Kondisi keuangan tidak berpengaruh terhadap pengungkapan informasi keuangan pada website resmi pemerintah daerah karena kondisi keuangan yang baik apabila tidak dibarengi dengan kesadaran betapa pentingnya transparansi informasi keuangan untuk mencegah asimetri informasi pada masyarakat serta kemampuan 
pemerintah daerah dalam memanfaatkan teknologi yang ada tidak akan mendorong pemerintah daerah untuk mengungkapkan LKPD pada website resmi pemerintah daerah.

\section{Pengaruh Kekayaan Daerah Terhadap Pengungkapan LKPD pada Website Resmi Pemerintah Daerah}

Hasil uji regresi logistik menunjukkan nilai signifikansi 0,023 yang lebih kecil dari $\alpha=5 \%$ atau 0,05. Dari hasil ini dapat disimpulkan bahwa variabel kekayaan daerah secara parsial berpengaruh signifikan terhadap pengungkapan LKPD pada website resmi pemerintah daerah. Artinya, semakin tinggi kekayaan daerah maka akan semakin tinggi pula kemungkinan suatu pemerintah daerah untuk melakukan pengungkapan informasi keuangan pada website resmi pemerintah daerah. Hasil penelitian variabel ini sejalan dengan rumus $\mathrm{H} 3$ yang dibangun oleh peneliti, dimana kekayaan daerah berpengaruh secara signifikan terhadap pengungkapan informasi keuangan pada website resmi pemerintah daerahnya. Pentingnya pengawasan yang dilakukan oleh masyarakat mengenai pengelolaan keuangan daerah juga harus dibarengi dengan kesadaran dari pemerintah daerah mengenai keterbukaan LKPD. Hal ini sangat penting untuk dilakukan mengingat sering kali terjadi asimetri informasi diantara masyarakat, namun sayangnya kesadaran akan hal ini cenderung masih rendah sehingga pemerintah daerah memilih untuk tidak melakukan pengungkapan LKPD pada website resminya.

\section{Pengaruh Kesejahteraan Masyarakat Terhadap Pengungkapan LKPD pada Website Resmi Pemerintah Daerah}

Hasil uji regresi logistik menunjukkan nilai signifikansi 0,654 yang lebih besar dari $\alpha=5 \%$ atau 0,05 . Dari hasil ini dapat disimpulkan bahwa variabel kesejahteraan masyarakat secara parsial tidak berpengaruh signifikan terhadap pengungkapan LKPD pada website resmi pemerintah daerah. Artinya, kesejahteraan masyarakat yang tinggi tidak menjadi acuan suatu pemerintah daerah untuk melakukan pengungkapan LKPD pada website resmi pemerintah daerah. Hasil penelitian variabel ini bertentangan dengan $\mathrm{H} 4$ yang dibangun oleh peneliti, dimana kesejahteraan masyarakat tidak berpengaruh secara signifikan terhadap pengungkapan LKPD pada website resmi pemerintah daerahnya. Hal ini disebabkan tingkat political monitoring masih relatif rendah. Sesuai dengan teori terdahulu yang menyatakan bahwa semakin tinggi kesejahteraan masyarakat maka semakin tinggi pula pengungkapan LKPD pada website resmi pemerintah daerah, hal ini dikarenakan semakin tinggi pula political monitoring yang dilakukan masyarakat, begitu pula sebaliknya.

\section{REKOMENDASI DAN KEBIJAKAN}

Tujuan dari penelitian ini adalah untuk menguji pengaruh dari variaberl independen terhadap variabel dependen. Sampel dari penelitian ini adalah LKPD ke- 34 provinsi yang ada di Indonesia pada tahun 2017. Selain itu tujuan lain dari penelitian ini adalah untuk mengetahui apakah variabel independen memiliki pengaruh secara simultan dan parsial terhadap variabel dependen.

Secara simultan variabel independen berpengaruh signifikan terhadap variabel dependen. Secara parsial hanya variabel kondisi keuangan yang berpengaruh signifikan terhadap pengungkapan LKPD pada website resmi pemerintah daerah. 


\section{DAFTAR PUSTKA}

[1]Ardiansyah. (2015). Local Sources of Income, Capital Expenditures and Human. The Indonesian Journal Of Accounting Research, 317-334.

[2]Ghozali, I. (2018). Aplikasi Analisis Multivariate dengan program IBM SPSS 25. Semarang: Badan Penerbit Universitas Diponegoro.

[3]Hendriyani, A., \& Tahar, A. (2015). Analisis Faktor-Faktor yang Mempengaruhi Tingkat Pengungkapan Laporan Keuangan Pemerintah Provinsi. Jurnal Bisnis dan Ekonomi (JBE) Vol 222, No1.

[4]]dris, A. L., Surasani, N. K., \& Irawan, M. (2018). The Determinan Disclosure of Internet Financial Reporting in District and City Government in Indonesia. IJER - Internet J. Eco. Res.

[5]|stikomah, \& Mutmainah, K. (2017). Determinan Publikasi Laporan Keuangan Pemerintah Daerah Melalui Internet. FE UNISIQ Vol. 12 No.1.

[6]Khasanah, I. N., Yuhertiana, I., \& B, G. S. (2017). Determinan Aksesibilitas Internet Financial Reporting (IFR) Pemerintah Ibu Kota Provinsi di Indonesia. Simposium Nasional Akuntansi XX Jember.

[7]Pemerintah, R. (2003). Undang-Undang No. 17 tahun 2003 tentang Keuangan Daerah. Jakarta : Pemerintah RI.

[8]Pemerintah, R. I. (2010). Peraturan Pemerintah No. 71 tahun 2010 tentang Standar Akuntansi Pemerintah. Jakarta: Pemerintah Republik Indonesia.

[9]Putri, W. M., \& Azra, F. I. (2019). Analisis Faktor-Faktor yang Mempengaruhi Tingkat Pengungkapan Wajib Laporan Keuangan Pemerintah Daerah (Studi Empiris pada Kabupaten/ Kota Se-Sumatera Barat Tahun 2015-2017). JEA (Jurnal Eksplorasi Akuntansi), Vol 1, No 3, Seri C.

[10Rahim, W. M., \& Martani, D. (2016). Analisis Faktor-Faktor yang Mempengaruhi Transparansi Informasi Keuangan Daerah Via Website. Simposium Nasional Akuntansi XIX Lampung.

[11]Rintoga, I. T. (2014, Maret 06). Analisis Laporan Keuangan Pemda. Diambil kembali dari Direktorat Jendral Bina Keuangan Daerah Kementrian Dalam Negeri: https://jurnal.bppk.kemenkeu.go.id/jurnalbppk/article/download/46/78/

[12]Suwarjono. (2014). Teori Akuntansi (Perekayasaan Pelaporan Keuangan) Edisi Ketiga. Yogyakarta: BPFE.

[13]Verawaty. (2015). Determinan Aksesibilitas Internet Financial Reporting Melalui E-Government Pemerintah Daerah. eprints Binadarma. 